DOI: $10.20472 /$ TE.2016.4.4.003

\title{
IS NEOLIBERALISM CONSISTENT WITH INDIVIDUAL LIBERTY? FRIEDMAN, HAYEK AND RAND ON EDUCATION EMPLOYMENT AND EQUALITY
}

\author{
IRIT KEYNAN
}

\begin{abstract}
:
In their writings, Milton Friedman, Friedrich August von Hayek and Ayn Rand have been instrumental in shaping and influencing neoliberalism through their academic and literary abilities. Their opinions on education, employment and inequality have stirred up considerable controversy and have been the focus of many debates. This paper adds to the debate by suggesting that there is an internal inconsistency in the views of neoliberalism as reflected by Friedman, Hayek and Rand. The paper contends that whereas their neoliberal theories promote liberty, the manner in which they conceptualize this term promotes policies that would actually deny the individual freedom of the majority while securing liberty and financial success for the privileged few. The paper focuses on the consequences of neoliberalism on education, and also discusses how it affects employment, inequality and democracy.
\end{abstract}

\section{Keywords:}

Neoliberalism; liberty; free market; equality; democracy; social justice; education; equal opportunities; Conservativism

JEL Classification: B20, B31, P16

\section{Authors:}

IRIT KEYNAN, College for Academic Studies, Israel, Email: iritike@gmail.com

\section{Citation:}

IRIT KEYNAN (2016). Is neoliberalism consistent with individual liberty? Friedman, Hayek and Rand on education employment and equality. International Journal of Teaching and Education, Vol. IV(4), pp. 30-47., 10.20472/TE.2016.4.4.003 


\section{Introduction}

Neoliberalism gradually emerged as a significant ideology during the twentieth century, in response to the liberal crisis of the 1930s. It gained increasing popularity as an entirely new form of liberalism that could resolve the crisis of the Great Depression, and at the same time defend democracies from the reemergence of totalitarianism (Jones, 2014).

Over time, neoliberalism has become a mixture of non-homogeneous ideas, and it was defined by Thorsen (2010) as a "loosely demarcated set of political beliefs which most prominently and prototypically include the conviction that the only legitimate purpose of the state is to safeguard individual liberty, understood as a sort of mercantile liberty for individuals and corporations" (p. 203). ${ }^{1}$ Any action of the state beyond this role is unacceptable, and governments "ought to be minimal or at least drastically reduced in strength and size" (Thorsen, 2010, p. 203). Neoliberalism is based on shared ideas of political economic practices bound by the common denominator of striving to establish an agenda whose primary interest is political economy and not merely economics (Biebricher, 2015; Harvey, 2005; Saad-Filho \& Johnston, 2005). This agenda wishes to influence the political structure of democracies and the life of people's various spheres of life. It therefore affects all aspects of life, for better or for worse, including the education system - not only because it influences the way education is budgeted and administered, but also because it influences the students' world view. Alongside its influence, neoliberalism is surrounded by ferocious and emotional debate (Thorsen, 2010).

During the 1980s, Milton Friedman (one of the most prominent forefathers of neoliberalism) profoundly influenced numerous political leaders, such as Ronald Reagan in the US and Margaret Thatcher in Britain (Frazer, 1982). His and other free market advocators' ideas have been supported by prominent Republican and Conservative leaders since then, dominating policies of international institutions since the 1990s and influencing the global economy and countries around the world. Friedman also had a great influence on Chile during the 1970s as part of a group of economists dubbed 'the Chicago boys' because of their attachment to the neoliberal ideas of Friedman, who was from the University of Chicago. These economists were summoned to Chile to reconstruct its economy after Pinochet's coup, and to implement their ideas in this country (Harvey, 2005). Extreme libertarian ideas, such as those of Ayn Rand, are also still strongly promoted nowadays by the Tea Party in the US (the most conservative and neoliberal section of the US Republican Party).

The main goal of this paper is to explore to what extent the central arguments behind neoliberalism - especially its call for complete dominance of the free markets and privatization of public services, and its interpretation of the protection of private ownership of property - are consistent with actual freedom and liberty. ${ }^{2}$ It investigates

\footnotetext{
${ }^{1}$ Definitions of neoliberalism abound, but they all are similar to the one provided here.

2 For the purpose of convenience, the term 'neoliberalism' in this paper is used to incorporate the above set of ideas, and the term neoliberals is used to describe theoreticians, scholars and politicians who identify with these concepts.
} 
the implications of neoliberalism in terms of the right to education, proper work conditions and living with dignity, which are parts of human rights according to the United Nations International Covenant on Economic, Social and Cultural Rights (United Nations, 1966). The paper addresses the meaning of personal liberty, and raises the question of to what degree does the way neoliberals interpret freedom strips it from its real meaning. Moreover, the paper investigates whether the severe limitations that neoliberalism imposes on governments' ability to execute social and economic policies are consistent with the democratic principle of the rule of the people (since neoliberalism effectively replaces it with the rule of capital).

The paper limits itself to the writings of Milton Friedman, Friedrich Hayek and Ayn Rand, since neoliberal writers - although all sharing some common ideas of free markets and minimization of government intervention - differ quite considerably in the strength of their convictions and the emphasis they put on different issues. In light of the great number of distinguished neoliberals, it would then be prohibitive to analyze all of them or even a fraction of them. ${ }^{3}$ Friedman, Hayek and Rand were chosen because of their high visibility and their major influence in academia and in the literature. ${ }^{4}$ They also span a wide range of different brands of conservatism and of periods of time, and represent both academia and literature, thus covering most of the essence of the ideology.

The following section looks at the neoliberal views on education, equality and employment. The paper's third section explores the implications of these views on the relations between neoliberalism and democracy. The paper ends with conclusions.

\section{Freedom for Whom?}

\section{II.1 Education and equality}

There is a wide consensus of the importance of education for the individual as well as for the collective, whether for economic reasons (Rand, 1986) or for both economic and democratic reasons (Friedman, 1955; Hayek, 1978). All three writers, however, call for a free economic market in the field of education with minimal public funding, dedicated only to the very basic education needed for a stable democratic state (Friedman, 1955; Hayek, 1978), or even to "liberating" education from government control altogether, abolishing all compulsory education (Rand, 1986). Over the years, the idea of privatizing schools has gained growing support among scholars with

\footnotetext{
3 The term neoliberalism was coined by Alexander Rüstow, and the concept was first defined in 1938 at the Colloque Walter Lippman that was convened to renew liberalism. Some of the greatest thinkers of the time economists, political scientists, philosophers and historians, such as Raymond Aron, Friedrich von Hayek, Walter Lippmann, Ernest Mercier, Robert Marjolin, Ludwig von Mises, Wilhelm Röpke, Louis Rougier and Alexander Rüstow, participated in the conference.

${ }^{4}$ While both Ludwig von Mises and Friedrich Hayek are the two best known Austrian economists, Hayek came to be better known, and although their economics are quite close, Hayek received the Nobel Prize (and von Mises did not). Our choice of Hayek over von Mises for this paper was, however, not an easy one to make. Examples for von Mises' views can be found in his books: von Mises $(1951,1953,2006)$. Murray Rothbard also was central in the Austrian school, but his influence on academia has not been as great as theirs.
} 
neoliberal views (Weil, 2002), who keep advocating for implementing privatization due to what they believe would improve educational results ${ }^{5}$ (Coulson, 2009).

In his book The Constitution of Liberty, first published in 1960, Hayek (1978) asserts that knowledge is necessary for modern society, and accepts that "the utilization of knowledge can be greatly increased by deliberate efforts" (p. 376). Based on this understanding, Hayek agrees that parents and guardians should not be unrestrictedly allowed to treat their children as they like, and should be forced to provide their children with a certain minimum education. He nevertheless prefers it to be in the form of private education, using minimal public resources, which would be disseminated by Friedman's idea of "vouchers" (Hayek, 1978). Subsidizing education by the state, according to Friedman, should be a function of the evaluation of the social gain, which he presumes is the greatest at the elementary levels of education (Friedman, 1955). Hayek (1978) seconds this idea, explaining that "all of us will be exposed to less risks and will receive more benefits from our fellows if they share with us certain basic knowledge and beliefs. .... democracy is not likely to work ... with a partly illiterate people" (p. 382). This conviction notwithstanding, Hayek and Friedman believe that the schools providing this basic education should not be run by government and should be mostly funded by the parents. The voucher system, they contend, will force all parents to give their children minimal education. This permits those who can afford it to pay for the costs of an improved level of education, which is considered an investment in an individual's future by his/her parents (Friedman, 1955).

Neither Hayek nor Friedman address the unavoidable worry that those who cannot afford the extra payments will have to provide their children with inferior education, limiting the destiny of their future as one of lower achievement. Moreover, when discussing higher education, Hayek (1978) advocates restricting funding for a "comparatively small elite", thus getting "maximum economic return from a limited expenditure" (p. 387). When deliberating the way to choose these privileged youngsters, he acknowledges the risk of growing social gaps, as the less fortunate "might become seriously neglected" (p. 383), but does not offer any solutions. He also ignores the fact that the odds of a child who was born into a poor family to be eligible for such a privilege is dramatically low, as his/her elementary and high school education will not be competitive.

A far more extreme attitude is presented by Ayn Rand (1986), who objects to the very idea of public education. In her book Capitalism: The Unknown Ideal, first published in 1966, she claims that compulsory public education is a totalitarian intervention into parents' decisions about their children. In this sense, she is consistent with the Libertarian's adhesion to negative freedom as an absolute abstinence of the government from any interference in the decisions and choices of the individual. (According to this view children are not eligible for such freedom, and if, for example, their parents decide not to educate them, the child has no legal recourse.) Her other argument against public schools stems from the same interpretation of freedom from

\footnotetext{
5 The issue of the quality of private schools has been debated, but is not discussed here, since this paper focuses on the question of making parents pay for their children's education.
} 
any intervention, which leads her to object to taxes in general, and in particular to taxing citizens for the education of children who are not their own:
"Should citizens have their wealth expropriated to support an educational system which they may or may not sanction, and to pay for the education of children who are not their own? To anyone who understands and is consistently committed to the principle of individual rights, the answer is clearly: No." (Rand, 1986, p. 93).

Whereas Hayek's deliberation on how to choose the few whose higher education will be funded by the state may be interpreted as competition based on talent. Rand and Friedman believe in a predestined future of those children whose parents cannot afford to enroll them in high quality private schools, preparing them for higher education. "There will always be situations in which parents are too poor to educate their children" says Rand; "Those children must rely on the charity or the self-interest of others" (cited in Podritske 6 , 2009, p. 83). According to Rand, while the state should not interfere with its citizens' life, it also has no obligation toward them. Good education, therefore, is a privilege secured by those who can pay for it. Moreover, the wealthy are "free" to decide whether it is in their interest to finance education for the poor as charity, which will later serve them:

$" . .$. it is in the interest of industrialists to have an educated work force ... Companies run specialized schools to train future employees, not for any mawkish, altruistic reason, but for a very proper, selfish reason: they need skilled employees" (cited in Podritske, 2009, p. 83).

In other words, in Rand's world the poor depend on the self-interest of capital owners. In fact, children of poor families who are not lucky enough to dwell where such a school exists are predestined to fit only the lowest paying jobs, those that do not require any training. Friedman is less blunt, but describes a similar notion in which those who are unable to pay for a better education will have to settle for the minimum provided by the state (Friedman, 1955).

These views expose an inner contradiction in neoliberalism's attitude towards freedom, which sees liberty only as a negative right. A comprehensive discussion of negative and positive liberty is far beyond the scope of this paper. It should be noted, however, that the concept of negative freedom calls for protection from external coercion, and contends that the state should guard individuals' freedom by not interfering with their choices, goals or decisions, and by not restraining their efforts of achieving them (Christman, 1991). This view, which strives to defend individuals from the government's arbitrariness, was naturally supported by liberals such as Isaiah Berlin (1969), who experienced and feared the devastating results of rulers' despotism. This, however, does not mean reducing liberty to its narrowest definition

\footnotetext{
${ }^{6}$ Podritske (2009) is a collection of interviews with Rand, presenting her ideas in her own words.
} 
of what government should not do. Positive liberty, on the other hand, is interpreted as the ability of a person to achieve self-fulfillment, and contains both the absence of restraints (negative liberty) and the capacity for self-government, which requires, among other things, the capability to formulate preferences in a way that is not the result of limited choices (Christman, 1991). Designating children of poor families to receive an inferior education definitely limits their choices, and therefore does not allow them (or at least puts heavy limitations on their efforts) to carry out their desires and wishes. Moreover, as Sen (1985a, 1985b, 2001) and Nussbaum (1997, 2000) argue, freedom is tightly connected to capabilities and choices. Sen (1985b) provides the example of two starving people, identical in all respects except that person A is starving because "she is very poor and lacks the means to command food", while person $B$ is starving "out of choice, because of his religious beliefs which have make him decide to starve and undergo the consequent suffering" (p. 201). Although the outcome of their starvation may be the same, Person B, in this example, is free, while person A is not, as she did not have the capability to choose not to starve. Analogously in the realm of education, consider a child of an affluent family and a child of a poor family, both of whom were not enrolled in higher education. The former is free even if he/she does not fulfill her potential; the latter does not have the capability to choose, and consequently he/she is not free. Thus, privatizing schools contradicts the idea of individual liberty, as it creates a situation in which only some are eligible for complete freedom. Those who do not have the resources to invest in their future are denied what Sen calls "well-being freedom" (Sen, 1985b, p. 201). Sen, in his many publications (e.g., 1985a, 1985b, 1982, 1992, 2001, 2014) argues against the dominant emphasis on economic growth as an indicator of a nation's quality of life; he believes rather that capabilities - what people are actually able to do - is the more relevant determinant of a nation's well-being.

The limiting effects of neoliberal policies on the lower classes became more acute over time. At the time when Friedman was campaigning for privatizing schools there was an increasing demand for educated workers with academic or highly professional degrees, the kind that "basic education" could not supply and many could not afford. More recently, unemployment rates of young people with limited education have been on the rise, a process that has affected Blacks and Hispanics more than Whites, thus increasing racial gaps (Hoynes, Miller, \& Schaller, 2012; Moore, 2015).

Theorists in all phases of neoliberalism, including Friedman and Hayek, accept the existence of substantive inequality (Jones, 2014). For neoliberals, attempts to narrow economic gaps, even by moderate redistributions of income or resources, are undesirable and constitute illegitimate intervention. Ignoring embedded structural gaps, neoliberals believe that in a free market different individuals have different capabilities which the market evaluates differently, and society or government should not intervene in this evaluation process or in its outcomes.

Neoliberals such as Hayek and Friedman see equality of opportunities as an impossible idea designed to limit the wealthy, therefore violating the principle of 
freedom. Adhering to liberty as a totally negative right, Hayek (1978) suggests that the only meaning of equal opportunity is "a career open to all talents" (p. 131), where access is unrestricted by arbitrary obstacles such as color, religion or gender. In his view, this limited interpretation of equality is the only feasible alternative to what he sees as a Communist version of equality. Friedman concurs, and in his book Free to Choose he asserts that Thomas Jefferson's words "all men are created equal" should not be interpreted literally (Friedman \& Friedman, 1990). Both scholars ignore the structural inequalities that prevent members of lower socio-economic classes from realizing their full potential based on their talents. A good example is Friedman's statement that "One child is born blind, another with sight. One child has parents deeply concerned about his welfare who provide a background of culture and understanding; another has dissolute, improvident parents" (Friedman \& Friedman, 1990 , p. 131). In other words, society should not interfere in individual luck as a predestined starting point. For both of them, inequality in itself is acceptable, as long as the market is blind to color, ethnicity and gender. The government, Hayek (1978) contends, should not compensate those who are unable or unwilling to change their fate, which in Hayek's view means treating them unequally for their lack of success (Jones, 2014).

In reality, however, mobility is not as likely as Hayek and Friedman would have us think. Empirical data show that under neoliberal rule, socio-economic mobility is becoming less possible. In the US, for example, mobility statistics no longer support the country's image of the land of opportunity, and there is a significant positive correlation between the socio-economic status of parents and that of their children (Chetty, Hendren, Kline, \& Saez, 2014). Moreover, this study asserts that the structural factors that erode the socio-economic status of the middle class impede intergenerational mobility. In this context, it is important to note the impact of privatization of public housing in the US and Britain, where landlords' racism and discrimination against people of color has increased segregation, worsened dwelling conditions (Jones, 2014), and ultimately reduced the mobility odds of public housing residents.

As neoliberalism and a free market economy triumphed in the US, corporate values have had a huge impact on social institutions such as universities, and especially on decisions involving budgets, tuition and allocation (Keynan, 2014). Thus, between the 1990 s and the first decade of the 21 st century, tuition at 4-year public colleges and universities increased by $47 \%$ (Giroux, 2005). In 2000, covering tuition called for $25 \%$ of the income of families in the lowest quintile, but only $7 \%$ and $2.5 \%$ of the income of third and first quintile families, respectively. The median income of entering freshmen at the 297 colleges participating in the American Freshmen Survey rose from 46\% above the national average in 1971 to $60 \%$ above the national average in 2005 (Pryor, Hurtado, Saenz, Santos, \& Korn, 2007). It is no wonder, then, that only $2 \%$ of the students in the 146 most selective colleges and universities in the US come from the bottom socioeconomic quarter of the American population (Michaels, 2012). Moreover, despite financial aid programs and scholarships, family wealth and income 
remain the best predictors - surpassing academic preparation - of who will attend university and at which institutions (National Center for Public Policy and Higher Education, 2000). In other words, higher education - the gate to economic success has long ceased to be "a career open to all talents". Instead, it is open only to those talented individuals who have the resources to pay for it.

Who are those who can pay? In 2011, Blacks accounted for about $12.6 \%$ of the general population in the US (US Census Bureau, 2011), and $11 \%$ of all enrollees in four-year colleges, but only about $5 \%$ of all enrollees in elite universities (Michaels, 2012). According to Lost Opportunity, a US national report prepared in 2009 by the Schott Foundation for Public Education (2009), Native American, Black, Hispanic, and Latino students, taken together, have just over fifty percent of the probability of studying in the nation's best-supported, best-performing schools compared to the nation's White, non-Latino students.

Structural disparities create a situation in which progress made by low-income US students in their academic course achievements does not reduce the gaps between them and their wealthier peers. Jackson et al. (2008) show that while low-income students in the US have made substantial gains in their academic course achievements since the 1970s, wealthier students have made even stronger gains over the same period, in both course grades and test scores, securing their competitive advantage in the market for selective college admissions. Thus, even when low-income students satisfy the academic admission requirements of selective, top-tier schools, stratification largely remains unchanged (Bastedo \& Jaquette, 2011). Friedman's words, quoted earlier in the paper, express a deep-seated prejudice against the poor, whom he regards as "dissolute and improvident" to their children's misfortune (Friedman \& Friedman, 1990, p. 131), and who therefore are blamed for their and their children's hardships. Friedman is not alone in this culturally unjust misrecognition, which is closely connected to distributive injustice (Fraser, 2009). This injustice is one of the major reasons why Black individuals, for example, have a greater probability of being poor than Whites, as is clearly reflected in the lower percentage of Black individuals in high-ranking universities compared with their overall enrolment in higher education. As much as Black parents may struggle to provide their children with the best education and prospects, structural gaps will continue to keep them behind, both because they have fewer opportunities for high quality education and because of such misrecognition. In their recent nation-wide study, Grissom and Redding (2016) found that a Black child in the US is half as likely as a White child to be included in programs for gifted children, and that this gap is almost the same for Hispanic children. The researchers found that one of the main reasons is misrecognition by non-Black and non-Hispanic teachers, who under-evaluate the brilliance of high achieving Black and Hispanic children. "In particular," the researchers write, "we uncover evidence that Black students in classrooms with non-Black teachers are systematically less likely to receive gifted services" (Grissom \& Redding, 2016, p. 14). There are, of course, exceptions, but their rarity emphasizes the rule. Government intervention can change this situation through regulation and investments in the necessary resources, but neoliberalism strongly objects to any government intervention, and especially the kind 
of involvement needed to reduce gaps in access to opportunities. One may even say that by urging governments to privatize schools, neoliberals are using government policy to ensure that structural gaps persist from generation to generation.

\section{II.2. Employment}

Limited choices for those without capital continues after education, in the labor market, where the rights of low-wage workers are restricted and violated, sometimes even in direct contradiction to the United Nations 1948 Declaration of Human Rights. A good illustration of support for this situation is Friedman's statement in his PBS TV series "Free to Choose" (Freidman \& Friedman, 1980), based on his 1980 book of the same name. Considering Hong Kong as a role model of a free market economy, the camera follows Friedman as he enters a shabby workshop for ivory sculptures, where he says,

"The workers here are some of the best paid in Hong Kong. It's hot,
sticky and extremely noisy. The workers are highly skilled, so they
can command high wages. They could induce their employer to
improve working conditions by offering to work for less. But they
would rather accept the conditions, take the high wages, and spend
them as they wish. That's their choice" (Episode 1, minute 14:15 -
14:50).

The idea that a worker should forego wages in order to receive reasonable working conditions is not only a distressing testimony to Friedman's interpretation of choice and workers' rights, but also contradicts Article 23 of the United Nations Declaration of Human Rights, which clearly states that everyone has the right to "just and favorable conditions of work." Furthermore, in the unregulated market with no minimum wage envisioned by Friedman (Friedman \& Friedman, 1990), the "high wage" he attributes to the skilled Hong Kong employees may very well be below the minimum needed for living with dignity. Friedman, however, views such bargaining as a "voluntary transaction" between free people, and blatantly disregards the fact that low-wage employees cannot truly choose among employers, or that neoliberal opposition to state welfare systems forces poor employees to agree to inhumane work conditions. Like Friedman, Rand (1964) also objects the regulation of minimum wage: "There are no rights to a 'fair' wage ... if no one chooses to pay it" (p. 9), she claims. This statement is based on what she sees as the only appropriate right, which is the right to property interpreted as the right to act with no interference either by other people or by government. Minimum wage in her view means that "some men are entitled by right to the products of the work of others" who therefore "are deprived of rights and condemned to slave labor" (Rand, 1964, p. 7). It is puzzling that she does not see that the same condemnation of slave labor applies to workers who are not entitled to a minimum wage and reasonable work conditions. On the contrary, she sees the right of living with dignity, "to earn enough to provide adequate food and clothing and recreation", as a violation of the capital owner's right to property, and condemns the 1960 Democratic Party platform that includes this right (Rand, 1964). 
While Friedman is not that blatant, his statement that highly skilled workers can "choose" to be paid less in return for the privilege of breathing fresh air reveals the neoliberal view of employees as "inputs" necessary to generate the desired "output" profits. As labor, employees are no different from other inputs such as machinery, raw materials and land (Elson, 2015), and no regard for feelings is given. ${ }^{7}$ While this approach may be reasonable for highly skilled workers, it is less so for low-skilled laborers. An investment banker may negotiate with his/her employers for fewer hours or can enjoy more leisure by switching to a teaching job. Such opportunities are hardly relevant for a factory worker.

Neoliberal opposition to regulated work conditions and minimum wage (Friedman \& Friedman, 1990; Rand, 1964) creates a market where might makes right, and where workers' only freedom is the freedom to compete against each other for the lowest wage, without any assurance that these wages will suffice for providing for their families, or that their job will be waiting for them the next day. Clearly, such workers do not have the capability to make choices (Sen, 1985a,1985b), and therefore are not free. The idea that low income workers are engaged in a "voluntary transaction" and are free to choose among options is not only false, but promotes a distorted interpretation of freedom as the privilege of owners of capital, putting new chains on all others (Gill, 2001, cited in Elson, 2015).

\section{Implications for Democracy}

Neoliberal ideas have been adopted by politicians in various countries, thus becoming an actually implemented political ideology and not merely an academic concept. This is reflected, for example, in the influence of neoliberalism on the American president Ronald Reagan and British Prime Minister Margaret Thatcher, and nowadays on the US Republican Party.

The idea of "no society" and individual self-interest as a paramount concept was embraced by Thatcher in the 1980s. Rand's notion that "there is no such entity as society, since society is only a number of individual men" (Rand, 1964, p. 2), was adopted and literally cited by Thatcher, while defending her neoliberal policy of selfreliance under all circumstances, in an interview in Women's Own magazine, on September 23, 1987 (Margaret Thatcher Foundation, N.D.):

"Who is society? There is no such thing! There are individual men
and women, and there are families and no government can do
anything except through people and people look to themselves first".

\footnotetext{
7 Gary Becker, a leading Chicago economist, models the rational behavior of families in terms of economic variables. For example, in his 1973 paper (Becker, 1973) he provides a model predicting the success of marriages in terms of variables such as the couple's income, human capital and relative wages, and provides empirical support for his theory. In Becker (1976) he considers emotions such as altruism as a factor affecting human decisions, thus deviating from the traditional neoliberal view of self-interest as being the only motivator of people's decision making.
} 
Thatcher's denial of the very concept of society is especially significant because of its timing, coinciding with an intensive privatization process that was "applied as a philosophy on a sustained and continuing basis" (Young, 1986, cited in Marsh, 1991, p. 460), even when it failed to promote competition or reduce public expenditures (Young, 1986, cited in Marsh, 1991). The "no society" statement also came shortly she defeated the miners' strikes during the period of rapid decline of traditional UK industries such as coal mines and shipbuilding, which brought deep and widespread poverty to many families, especially in the northeast of England (Hudson, 2005). A similar influence is reflected in Reagan's famous statement, during his inaugural address on January 20,1981, that "government is not the solution to our problems, government is the problem" (Reagan Foundation, N.D.). These two leaders, who were deeply influenced by Milton Friedman (Jones, 2014), made clear that they accepted the ideas that put an end to the concept of social contract as a basis of democracy, replacing democratic choices with the power of those whose already solid socioeconomic status is further advanced by the governments' abstention from actions that may balance the supremacy of the strong, and allow the weak to improve their situation.

Neoliberalism would relinquish the government's responsibility for its citizens and impose a regime of self-reliance on families and individuals - society's "economic units" (Friedman, 1955) - regardless of the socio-economic circumstances or structure. Neoliberalism thus proposes to destroy society's social contract, forcing individuals and families to care independently for all their needs, including health and quality education. Combined with the neoliberal principle of privatization, this doctrine creates structural barriers for many who, locked in low wages with few or no social benefits, are unable to afford health insurance or to invest in quality education that promises future success. Regardless of this fundamental obstacle, neoliberal's core value of self-reliance sees the family as the sole bearer of responsibility for the welfare of its members. Those who fail to provide for their families according to the neoliberal standards of the corporate world are denounced for what neoliberalism considers an individual's failure to properly fulfill his or her obligations (Moore, 2015).

By prioritizing individual self-interest as the one motivation for all human actions, neoliberalism endangers not only the social contract, but democracy itself. Democracy is not a perfect system. One of its faults, according to public choice theory, is the difficulty of democratic institutions in taking decisions which are free of sectorial interests (Tullock, 2008). In addition, Arrow's seminal impossibility theorem (Arrow, 1950) shows that, loosely speaking, there is no voting system that can satisfy all voters. Neoliberalism took this assumption, together with the conviction of self-interest as a paramount and adherence to negative liberty, and brought them to the conclusion that governments should have as little power as possible, and be limited only to enforcing strong property rights (Rand, 1964; Thorsen, 2010).

Sen (2014) contends that "it will be a mistake to assume that preferences as they actually are do not involve any concern for others" (p. 6). On the contrary, he maintains, "the society in which a person lives, the class to which he belongs, the 
relation that he has with the social and economic structure of the community, are relevant to a person's choice not merely because they affect the nature of his personal interests but also because they influence his value system including his notion of 'due' concern for other members of society" (Sen, 2014, p. 6). The idea is not that people do not let their personal interests influence their actions, but that this is not the one and only motivation, and that as Rawls (2001) suggests, it is possible to create agreedupon procedures to overcome the rule of self-interest without dismantling the social contract or weakening democracy. This is Rawls' idea of justice as fairness, designing a system of setting society's laws and norms behind the veil of ignorance, thus preventing the bias of self-interest. Under the veil of ignorance, decisions about the rights and obligations of all citizens are made by individuals who have no knowledge of their own or their co-citizens' economic and social position, race, gender, ethnic group, etc. Moreover, according to Rawls, behind the veil of ignorance, "all are similarly situated and no one is able to design principles to favor his particular condition" (Rawls, 2009, p. 11). As a consequence, "the principles of justice are the result of a fair agreement or bargain" (Rawls, 2009, p. 11).

When discussing negative liberty, one should bear in mind its inherent endangerment of those who were not lucky enough to be born with economic resources, passed on from generation to generation. Neoliberal government is expected to prioritize property rights, and advocate privatization of assets and services, free trade and free markets, deregulation and the rule of law, especially contractual commitments, which are regarded as sacred (Harvey, 2005). In order to impose these mechanisms and guarantee negative liberty, the state is obligated to use its monopoly on power, enforcing market systems or inventing them if they are nonexistent. A good example is the invention of pollution-rights markets, which enable the trading of clean environment for money, as well as the self-imposed restrictions on development poor countries take upon themselves in exchange for desperately needed foreign currency. The pollution-rights markets allow wealthy industrial countries to offer the purchasing of pollution rights from poor countries, perpetuating the latter's underdevelopment, or to pay poor regions or countries to take their industrial waste. This view actually legitimizes environmental racism (Bullard, 1993), which causes disproportional harm to weak communities through the presence of industrial toxins in their workplaces and in their neighborhoods. While negative liberty is essential for political and cultural freedom, positive liberty is no less essential for protecting weak communities from such environmental evil. Naturally, neither Rawls nor Sen would have accepted such trade in pollution rights, because its outcomes will always favor the wealthy at the expense of the poor.

Neoliberalism's' free market also endangers democracy itself, because it leads to replacing democratic institutions - their problems notwithstanding - with the power of capital owners, which inevitably will always be at the expense of society's weakest sectors. This is especially true since neoliberalism denies individuals' their democratic freedom to organize and choose strong collective institutions to protect themselves against the adverse outcomes of free markets. 
Centralizing economic efficiency as the most important vector in society's life, inevitably leads to limiting democratic processes, which - in addition to their limitations according to public choice theory - are long and slow. This, according to neoliberalism, should not prevent or slow down neoliberal reforms, and if they do "then democracy ought to be sidestepped and replaced by the rule of experts or legal instruments designed for that purpose" (Thorsen, 2010, p. 205).

Moreover, neoliberalism presumes to define civil moral virtues as subordinate to market rules, while viewing injustice and inequality as morally acceptable. According to Friedman (1980), a good person or citizen is one who participates in the free market and who is able and willing to take the risks, while accepting the sole responsibility for any good or bad results. In other words, Friedman, like Hayek (1978), saw inequality as morally acceptable as long as it is seen as the consequence of a free decision (Thorsen, 2010), while ignoring the unfree situation of those in low economic classes.

In sharp contrast to neoliberal acceptance of inequality, Rawls (2001) contends that no one should be advantaged or disadvantaged - either by the natural chance of talent, or by social circumstance. While inequality is bound to evolve over time even in a reality of equal opportunities, democratic social contract is committed to exploring ways of overcoming this situation. Such is Rawls' (2001) call to use inequality to benefit the weakest sectors of society, ensuring that the weak have a chance at mobility. Rawls' goal, like that of Hobshouse before him (Dimova-Cookson, 2012), Sen (1985a, 1985b) and Nussbaum (2003), is to eliminate injustice and create a fair society, allowing the have-nots to improve their lives without harming those who have.

The gap between these views, and the inner contradiction in the neoliberal interpretation of negative liberty, are reflected in the deliberately extreme example brought by Nozik (1974), according to which the starving woman at the door is not even allowed the crumbs that fall off the table of the rich, if it denies the rich the pleasure of giving them to their birds. The outcome of these different approaches is not only reflected in their view of morality, but it also translates into different concepts of democracy. Rawls' theory leads to a democratic citizenship in which all women and men are free and equal, entitled to equal rights and opportunities, and share responsibility for each other within the framework of the social contract of the state, for which they choose their equal representatives. The idea of equality in Rawls' theory commits society to guaranteeing equal opportunities and freedom and preventing massive growth of social differences over generations, but allowing inequality based on personal endeavors. In other words, according to Rawls, gaps between the poor and the rich are legitimate and unavoidable, as long as society continues to invest in resources and efforts to facilitate social mobility opportunities for the poor. Neoliberalism, on the other hand, views the relations between citizens and the state via the lens of public choice theory and negative freedom, prioritizing economic efficiency over all other considerations, thus concluding in replacing the system of democratically chosen representatives with rule by the economic elite that uses the law to perpetuate its dominance (Harvey, 2005). Thus, whether intentional or not, 
neoliberalism undermines the basic democratic principle of the right of the majority to make decisions through its democratically elected institutions.

\section{Conclusion}

This paper explored to what extent the writings of some of the forefathers of neoliberalism - Friedman, Hayek and Rand, who expound freedom - are consistent with policies that would lead to achieving such goals. It was shown that their theories would actually lead to denial of freedom for the majority of people. Following Sen (1985a, 1985b), the paper contends that for freedom of choice to be viable (the capabilities approach), the choice must be feasible or else it is specious. In this sense the freedom promoted by Friedman, Hayek and Rand would be feasible only to a few, and by and large the general population would enjoy very limited genuine liberty. Their policies, the paper shows, would lead to an education system which provides superb service to a small minority while excluding the majority from decent schooling. In addition,, the way quality education is allocated according to these writers is profoundly biased in favor of the affluent. Since employment and income heavily depend on education, and the race for Harvard starts at kindergarten or earlier, the neoliberal system actually stifles social and economic mobility, which is one of the landmarks of freedom. The US has long been touted as the land of opportunity, where - loosely speaking - "anyone can achieve anything". The neoliberal education policies, however, would make this promise empty regarding most people. Neoliberalism therefore facilitates the evolving of a new aristocracy which supposedly allows free entrance into its ranks, based only on talent and economic success, but in practice denies access to those who were born to lower socio-economic classes.

Neoliberalism's assumption that employer-employee relations are voluntary transactions between free people (Friedman \& Friedman, 1990) also does not differentiate between a viable and a non-viable choice. Assuming that workers could bargain with (often monopsonistic) employers on worker's conditions makes the prevalence of poor working conditions seem acceptable, whereas it clearly is not. ${ }^{8}$ Similar arguments by neoliberals are also made to oppose minimum wage policy, insisting that it harms the economy and increases unemployment, although there the evidence for this is mixed. ${ }^{9}$ Objections to minimum wage, combined with proposing reduced welfare for the poor, also have dangerous implications for democracy, since

\footnotetext{
${ }^{8}$ Chicago economists such as Stigler (1971) acknowledged the detrimental effects of monopolies, but suggested that their regulation could lead to even worse effects. Friedman's account of his visit in the Hong Kong factory does not fit Stigler's examples well. In addition, neoliberals' reliance on free markets often ignores the many detrimental effects of market imperfections, such as asymmetry of information and transaction costs. Akerlof's seminal paper (Akerlof, 1970) on the theory of markets under asymmetric information appeared only in 1970, and the vast body of literature based on this theory emerged only later - too late to influence the early neoliberals.

${ }^{9}$ In a micro-analysis, wage restrictions (minimum wages) are likely to cause unemployment. However, in a macroanalysis their effects are not straightforward and hard to predict. The empirical evidence on how wage restrictions actually affect unemployment varies. According to Card and Krueger (1993), Katz and Krueger (1992), and Schmitt (2013), increasing the minimum wage does not affect unemployment. Addison, Blackburn and Cotti, 2013, found no effects of minimum wages on unemployment, but mixed results of such policies in their 2012 study. Neumark, Salas and Wascher (2014) discovered that minimum wages may increase unemployment, and Newmark and Wascher (2015) argued that the evidence suggests it is appropriate to weigh the cost of potential job losses from a higher minimum wage against the benefits of wage increases for other workers.
} 
a lack of subsistence security in vast sectors of society may propel them into the arms of religious or other extremist movements that are responsive to these needs (Mautner, 2013).

Having shown that the policy implications of the writings of Friedman, Hayek and Rand are inconsistent with their claim for striving for freedom and liberty, one wonders how other significant neoliberal ideologists fare in this respect. In addition, although the theories of Friedman, Hayek and Rand on the advantages of minimal government intervention and a widespread free market in education lead to undesirable consequences, it is possible that the consequences of a greater reliance on the state could be more detrimental. This raises the question of whether, instead of relying on the extremes, researchers should look for an optimal balance between market intervention and free market. The answers to these questions, however, are beyond the scope of this paper and are left to future research.

\section{References}

Addison, J. T., Blackburn, M. L., \& Cotti, C. D. (2012). The Effect of Minimum Wages on Labour Market Outcomes: County-Level Estimates from the Restaurant-and-Bar Sector. British Journal of Industrial Relations, 50(3), 412-435. https://doi.org/10.1111/j.1467-8543.2010.00819.x

Addison, J. T., Blackburn, M. L., \& Cotti, C. D. (2013). Minimum wage increases in a recessionary environment. Labour Economics, 23, 30-39. https://doi.org/10.1016/j.labeco.2013.02.004

Akerlof, G. A. (1970). The market for "Lemons": Quality uncertainty and the market mechanism. The Quarterly Journal of Economics, 84(3), 488-500. https://doi.org/10.2307/1879431

Arrow, K. J. (1950). A difficulty in the concept of social welfare. The Journal of Political Economy, 328346. https://doi.org/10.1086/256963

Becker, G. S. (1973). A theory of marriage: Part I. The Journal of Political Economy, 813-846. https://doi.org/10.1086/256963

Becker, G. S. (1976). Altruism, egoism, and genetic fitness: Economics and sociobiology. Journal of Economic Literature, 14(3), 817-826.

Bastedo, M. N., \& Jaquette, O. (2011). Running in place: Low-income students and the dynamics of higher education stratification. Educational Evaluation and Policy Analysis, 33(3), 318-339. https://doi.org/10.3102/0162373711406718

Berlin, I. (1969). Two concepts of liberty. 118-172.

Biebricher, T. (2015). Neoliberalism and democracy. Constellations, 22(2), 255-266. https://doi.org/10.1111/1467-8675.12157

Bullard, R. D. (1993). Confronting environmental racism: Voices from the grassroots. Cambridge, MA: South End Press.

Card, D., \& Krueger, A. B. (1993). Minimum wages and employment: A case study of the fast food industry in New Jersey and Pennsylvania (No. w4509). National Bureau of Economic Research. https://doi.org/10.3386/w4509

Chetty, R., Hendren, N., Kline, P., \& Saez, E. (2014). Where is the land of opportunity? The geography of intergenerational mobility in the United States. The Quarterly Journal of Economics, 129(4), 1553-1623. https://doi.org/10.1093/qje/qju022

Christman, J. (1991). Liberalism and individual positive freedom. Ethics, 101(2), 343-359. https://doi.org/10.1086/293292

Coulson, A. J. (2009). Comparing public, private, and market schools: The international evidence. Journal of School Choice, 3(1), 31-54. https://doi.org/10.1080/15582150902805016

Dimova-Cookson, M. (2012). Liberty as Welfare The basecamp counterpart of positive freedom. Collingwood and British Idealism Studies, 18(2), 133-165. 
Elson, D. (2015). Gender justice, human rights and neoliberal economic policies. In S. Staab \& S. Razavi (Eds.), Gendered dimensions of development (pp. 37-64). Geneva: UNRISD (original work published 2002).

Fraser, N. (2009). Social justice in the age of identity politics. In G. L. Henderson \& M. Waterstone (Eds.), Geographic thought: A praxis perspective (pp. 72-91). London, UK: Routledge. https://doi.org/10.1080/00213624.1982.11504012

Frazer, W. (1982). Milton Friedman and Thatcher's monetarist experience. Journal of Economic Issues, 16(2), 525-533.

Friedman, M. (1955). The role of government in education. New Brunswick, NJ: Rutgers University Press.

Friedman, M. (1980): Free to choose. New York, NY: Harcourt Brace Jovanovich.

Friedman, M., \& Friedman, R. (1980). Free to choose [TV series episode Part 1]. In B. Chichester (Producer). United States: PBS.

Friedman, M., \& Friedman, R. (1990). Free to choose: A personal statement. New York, NY: Houghton Mifflin Harcourt.

Giroux, H. A. (2005). The terror of neoliberalism: Rethinking the significance of cultural politics. College Literature, 32(1), 1-19. https://doi.org/10.1353/lit.2005.0006

Grissom, J. A., \& Redding, C. (2016). Discretion and disproportionality. AERA Open, 2(1). doi:10.1177/2332858415622175

Harvey, D. (2005). A brief history of neoliberalism. Oxford, UK: Oxford University Press.

Hayek, A. F. (1978). The constitution of liberty. Chicago, IL: University of Chicago Press.

Hoynes, H. W., Miller, D. L., \& Schaller, J. (2012). Who suffers during recessions? (No. w17951). Cambridge, MA: National Bureau of Economic Research. https://doi.org/10.3386/w17951

Hudson, R. (2005). Rethinking change in old industrial regions: reflecting on the experiences of North East England. Environment and Planning A, 37(4), 581-596. https://doi.org/10.1068/a36274

Jackson, A. L., Zhao, Y., Kolenic, A., Fitzgerald, E. H., Harold, R., \& von Eye, A. (2008). Race, gender and information technology use: the new digital divide. CyberPsychology \& Behavior, 11(4), 437-442. https://doi.org/10.1089/cpb.2007.0157

Jones, D. S. (2014). Masters of the universe: Hayek, Friedman, and the birth of neoliberal politics. Princeton, NJ: Princeton University Press. https://doi.org/10.1515/9781400851836

Katz, L. F., \& Krueger, A. B. (1992). The effect of the minimum wage on the fast food industry. Industrial and Labor Relations Review, 46(1): 6-21. https://doi.org/10.3386/w3997

Keynan, I. (2014). Knowledge as responsibility: Universities and society. Journal of Higher Education Outreach and Engagement, 18(2), 179-206.

Marsh, D. (1991). Privatization under Mrs. Thatcher: a review of the literature. Public Administration, 69(4), 459-480. https://doi.org/10.1111/j.1467-9299.1991.tb00915.x

Mautner, M. (2013). Liberalism in Israel: Good persons, bad citizens, and the conditions of human flourishing. Tel Aviv UL Review, 36, 7. (Hebrew).

Michaels, W. B. (2012). The trouble with diversifying the faculty. Liberal Education, 97(1). Retrieved from

http://www.aacu.org/liberaleducation/le-wi11/LEWI11_Michaels.cfm

Moore, H. (2015). Is there a crisis in the family? In S. Staab \& S. Razavi (Eds.), Gendered dimensions of development (pp. 13-36). Geneva: UNRISD (Original work published 1994).

National Center for Public Policy and Higher Education (2000). Profiles of American college students. In Losing ground: A national status report on the affordability of American higher education (Chapter 7). Retrieved from http://www.highereducation.org

Neumark, D., Salas, J. I., \& Wascher, W. (2014). Revisiting the Minimum Wage - Employment debate: Throwing out the baby with the bathwater?. Industrial \& Labor Relations Review, 67(suppl. 3), 608-648. https://doi.org/10.1177/00197939140670S307

Neumark, D., \& Wascher, W. (2015). The effects of minimum wages on employment. FRBSF Economic Letter, 2015, 37.

Nozick, R. (1974). Anarchy, state and utopia. Oxford: Blackwell. 
Nussbaum, M. (1997). Capabilities and human rights. Fordham Law Review, 66, 273-300.

Nussbaum, M. (2000). Women and human development: The capabilities approach. Cambridge, UK: Cambridge University Press. https://doi.org/10.1017/CBO9780511841286

Nussbaum, M. (2003). Capabilities as fundamental entitlements: Sen and social justice. Feminist economics, 9(2-3), 33-59. https://doi.org/10.1080/1354570022000077926

Podritske, M. (2009). Objectively speaking: Ayn Rand interviewed. Lanham, MD: Lexington Books.

Pryor, J. H., Hurtado, S., Saenz, V. B., Santos, J. L., \& Korn, W. S. (2007). The American freshman: Forty year trends, 1966-2006. Los Angeles, CA: Higher Education Research Institute, Graduate School of Education, \& Information Studies, University of California.

Rand, A. (1964). Man's rights. Ayn Rand Institute.

Rand, A., (1986). Capitalism: The unknown ideal. London, UK: Penguin (with additional articles by Branden, N., Greenspan, A., and Hessen, R.).

Rawls, J. (2001). Justice as fairness: A restatement. Cambridge, MA: Harvard University Press.

Rawls, J. (2009). A theory of justice. Cambridge, MA: Harvard University Press.

Reagan Foundation Reagan, R., A speech at the presidential inauguration (January, 20, 1981). Available at the Reagan Foundation website, http://www.reaganfoundation.org/reagan-quotesdetail.aspx?session_args=E5071C26-B2CA-401A-BE5F-4F2D6725DD54\&tx=2072

Reid, J. (2013). "The Ayn Rand School for Tots": John Dewey, Maria Montessori, and objectivist educational philosophy during the postwar years. Historical Studies in Education/Revue d'histoire de l'éducation, 25(1), 73-94.

Saad-Filho, A., \& and Johnston, D. (2005). Introduction. In A. Saad-Filho \& D. Johnston (Eds.), Neoliberalism - A critical reader (pp. 1-6). London, UK: Pluto Press.

Schmitt, J. (2013). Why does the minimum wage have no discernible effect on employment? Center for Economic and Policy Research, 22, 1-28.

Schott Foundation for Public Education (2009). Lost opportunity: A 50 state report on the opportunity to learn in America. Retrieved from http://www.otlstatereport.org/.

Sen, A., \& Pattanaik, P. K. (1969). Necessary and sufficient conditions for rational choice under majority decision. Journal of Economic Theory, 1, 178-202. https://doi.org/10.1016/00220531(69)90020-9

Sen, A. (1982). Choice, welfare and measurement. Oxford, UK: Blackwell.

Sen, A. (1985a). Commodities and capabilities. Amsterdam: North-Holland.

Sen, A. (1985b) Well-being, agency and freedom: The Dewey lectures 1984. The Journal of Philosophy, 82(4), 169-221. https://doi.org/10.2307/2026184

Sen, A. (1992). Inequality reexamined. New York, NY and Cambridge, MA: Russell Sage and Harvard University Press.

Sen, A. K. (2001). Development as freedom. Oxford, UK: Oxford Paperbacks.

Sen, A. K. (2014). Collective choice and social welfare (Vol. 11). Amsterdam: Elsevier.

Stigler, G. (1971). The theory of economic regulation. Bell Journal of Economics and Management Science, April 1, 3-21. https://doi.org/10.2307/3003160

Thatcher, M. An interview in Women's Own magazine, on September 23, 1987, available at the Margaret Thatcher Foundation, http://www.margaretthatcher.org/document/106689

Thorsen, D. E. (2010). Neoliberal challenge - What is neoliberalism? Contemporary. Readings in Law and Social Justice, 2, 188-214.

Tullock, G. (2008). Public choice. The new Palgrave Dictionary of Economics (2 ${ }^{\text {nd }}$ ed.). London, UK: Macmillan.

United Nations (1966). http://www.ohchr.org/EN/Professionallnterest/Pages/CESCR.aspx

United States Census Bureau (2011). Transcript No. 036.24.2011. Retrieved from http://2010.census.gov/news/pdf/transcript_3-24-11.pdf.

von Mises, L. (1951), Socialism: An economic and sociological analysis. New Haven, CT: Yale University Press (Original work published 1922).

von Mises, L. (1953) The Theory of Money and Credit (Original work published 1912).

von Mises, L. (1912, 2006). Nation, state, and economy. Liberty Fund 
Weil, D. K. (2002). School vouchers and privatization: A reference handbook. Santa Barbara, CA: ABC-CLIO.

Westheimer, J., \& Kahne, J. (2004). What kind of citizen? The politics of educating for democracy. American Educational Research Journal, 41(2), 237-269. https://doi.org/10.3102/00028312041002237 